\title{
NATURE AND FRONTIERS OF WORDSWORTH'S "SPOTS OF TIME"
}

\author{
Brunilda Reichmann \\ Universidade Federal do Paraná
}

\section{RESUMO}

\begin{abstract}
Este trabalho explora um poema de Wordsworth intitulado "Resolution and Independence" com o objetivo de ilustrar a filosofia de criação poética do mesmo autor. Seleciona-se a expressão "spots of time", mencionada pela primeira vez na Introdução da segunda edição do livro Lyrical Ballads, marco do inicio do romantismo inglês, por carregar em si o germe de sua filosofia. Como demonstramos, este poema revela a natureza e delineia as fronteiras dos "spots of time".
\end{abstract}

We do not have to direct our attention immediately to Wordsworth's notion of "spots of time" to see how appropriate his expression is. Any dictionary definition of the word spot will lead us very close to the poet's meaning. The first usage of the word, suggested by Hornby, is: "Small mark different in colour from what it is on." 'Two characteristics or aspects are suggested by this definition: a contrast and a basic homogeneous background. If we take, for example, a piece of cloth, a spot can only be seen because its color is different from the color of the cloth and, at the same time, it can only be seen because of the cloth's homogeneity of color. The spot breaks the homogeneity, but depends basically on it. Such simple aspects are no less important in Wordsworth's notion of the works of the imagination in order to delineate a spot of time from time itself. In fact, the poet refers, in his "Preface", to the same idea of contrast in color suggested by Hornby." "Colouring of imagination" is the ex-

1 HORNBY, A.B. ct all. The advanced learner's dictionary of current English. London, Oxford Unlversity Press, 1967.

2 SELINCOURT, Ernest de. erl. Wordsworth: The Prelude. London. Oxford University Press, 1970. 
pression the poet uses in his "Preface" and in "Tintern Abbey" he shows how such coloring works among "recognitions dim an faint" background. This homogeneos background or the colorless quotidian reality is the basic foundation for Wordsworth's creation of "spots of time" or for his ilustration of the works of imagination at a given time.

Man has become, as a result of the pressures of this colorless quotidian reality, an insensitive begin incapable of building a world of inward happiness based upon colorful impressions and meaningful experiences. The poet, a highly sensitive being, should be able to awaken that man from his slumber-like contact with life, should be able to teach him how to break that homogeneous background with colorful imaginative spots. The poet should, therefore be able to teach man how to make common experiences unique by the works of the imagination.

The scope of this paper is to show how Wordsworth, as a poet, wants to confer the imaginative experience upon the reader by expressing the nature and delineating the frontiers of his "spots of time" in a poem. We should remind ourselves that Wordsworth's "spots of time" are not important only because of their effect upon the poet's present reality. They are also important because they become "life and food/For future years". " The poet's ability to recollect experiences intensely felt in the past or to relive those moments which make up his "living calendar" attach as twice as much importance to the experience.

"Resolution and Independence" is a puem based on recollection, on a felt experience which has been stored in the poet's memory, but its structure somehow differs from other poems based on recollection. The poem is developed in such a way as to present a would-be recollection in its process of development. We could call it a recollection within a recollection. The external frame presents a speaker who ponders about the beauty of nature after a storm and about the disharmony between such beauty and his state of mind. The internal structure presents a speaker who undergoes an experience which, by its intensity and significance, changes his previous view of nature.

Like many other poems by Wordsworth, "Resolution and Independence" begins with images from nature. The

3 NOYES, Russel, ed. Tiatern Abbes. In: —__ English romantic poetry and prose. New York, Oxford Unluersity press, 1956. p. 258.

4 NOYFB, p. 259.

5 NOYES, To my sister. D. 256.

6 Quotations from this poem are not tootnoted. 
whole of nature rejoices with the rising of the sun after a storm.

The birds are singing in the distant woods;

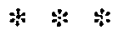

All things that love the sun are out of doors; The sky rejoices in the morning's birth;

The grass is brigth with rain-drops; on the moors The hare is running races in her mirth;

The speaker also feels an unconscious comunion with the mirth that surrounds him. But that "harmony" or "communion" suddlenly ceases to exist and "fear and fancies thick upon" the speaker coma and lead him to the realization that "We Poets in our youth begin in gladness;/ But thereof come in the end despondency and madness".

After this realization, the speaker's attention is directed toward the image of a lonely old man beside a pool. This stanza marks the beginning of the background necessary for the imagination to create another spot of time. The old man, a leech-gatherer, is described with vividness and imagination through similes and images which suggest inexplicability, primeval life, and motionlessness in stanzas nine, ten, and eleven. $\mathrm{He}$ is one with the nature that forms the background.

Motionless as a cloud the old Man stood, That heareth not the loud winds when they call;

And moveth all together, if it move at all.

But the poet had to separate this old man from the landscape not only to give him reality as a human being who will deeply impress the poet by his individual qualities, but also to enable the "I" to speak with his.

At length, himself unsettling, he the pond Stirred with his staff, and fixedly did look Upon the muddy water, which he conned, As if he had been reading in a book:

And now a stranger's privilege $\mathrm{I}$ took;

And, drawing to his side, to him did I say,

'This morning gives us promise of a glorious day.'

In other words, the speaker's intuition may be telling him that this encounter with the old man may produce "life and food/For future years."

7 See note 3. 
Two more times the speaker addresses the old man. The question the speaker will ask later on in the poem is a repetition" of the first question: "What ocupation do you there pursue?/ This is a lonesome place for someone like you." "But instead of presenting the old man's answer, the speaker goes on in the next lines and stanza to describe the old man's "yet-vivid eyes" and the solemnity of his speech. Only in stanza fifteen the speaker tells us about the old man's occupation. But the speaker says less than the leech-gatherer tells him. Not because he does not want to repeat what tha old man told him, but because the speaker's imagination begins to soar and he no longer has ears to listen to the old man's solemn words or eyes to watch him carefully as he did earlier when he described his figure.

The old man stood talking by my side;

But now his voice to me was like a stream

Scarce heard; nor word from word could I divide;

And the whole body of the man did seem

Like one whom I had met with in a dream;

What the old man says besides what the speaker tells us is of secondary importance. What is important is the effect this old man will have upon the speaker. We know that the old man is there, but at the moment the speaker's imagination works on the experience, the old man, as a consequence, becomes less real as a human being outside the poet. But, paradoxically and poetically, the old man becomes more real to the poet's inner life because at the moment the speaker refers to him as somebody he "met with in a dream" the leech-gatherer inhabits the speaker's mind-the shrine of his whole being.

But we would not know if the experience between the speaker and the old man had found a place in the poet's memory if it finished at the end of stanza sixteen. The first line od stanza seventeen ("My former thoughts returned: the fear that kills") does not allow us to know if the speaker did undergo a change by the experience he had. The speaker's imagination seems to stop working when the old man stops talking. His realm, to use Wordsworth's own expression, seems to vanish before its permanence is effected; it seems to vanish before the imagination can incorporate the experience into the speaker's life. That seems to be why, when speaker addresses the old man for the last time, he 
asks the same question he had asked before although he and we know the answer and although the question: "How is it that you live, and what is it you do?" "Is the same as saying: "keep on talking". The old man "with a smile did then his words repeat".

While he was talking thus, the lonely place, Tho old Man's sape, and speech-all troubled me: In my mind's eye I seemed to see him pace About the weary moors continually, Wandering about alone and silently White I these thoughts within myself pursued, $\mathrm{He}$, having made a pause, his discourse renewed.

The old man's words effect another immersion of the speaker into his own dream. This time, as if by an expansion of the imagination, the experience finds a permanent dwelling among the other "dreams" in the speaker's memory and furthermore the experience is incorporated into the speaker's being - it becomes final, and permanent.

'God,' said I, 'be my help and stay secure;

I'll think of the leech-gatherer on the lonely moor!'

It seems poetically valid to suggest that the experience the speaker undergoes is, in its essence or nature, a dream. Two aspects should characterize this dream: a contrast with and a dependence on the quotidian "dim and faint" reality. A dream, like a spot, has to be easily discernible from what surrounds it. The only way a dream can carry this quality is by its own birth and death. If the imaginative power which gives birth to the dream fails, the dream vanishes and so does the possibility of being detached from the background or from among common experiences. The dream has to die into meaningful experience in order to be discernible from the common experiences and in order to establish its permanence in the poet's memory. As the cause of a meaningful experience, the dream is not merely a result of indistinct perception of external reality but the utmost reality of the poet's inner life, and its birth and death mark the frontiers of each of his "spots of time."

\section{REFERENCIAS BIBLIOGRAFICAS}

1 HORNBY, A. S. et alii. The advanced learner's dictionary of current English. London, Oxford University Press, 1967.

2 NOYES, Russell, ed. English romantic poetry and prose. New York, Oxford University Press, 1956.

3 SELINCOURT, Ernest de, ed. Wordsworth: The Prelude. London, Oxford University Press, 1970. 